\title{
REPERTORIO BIBLIOGRAFICO SOBRE DERECHO ELECTORAL Y ELECCIONES EN ESPAÑA (1810-1936)
}

\author{
POR \\ OSCAR ALZAGA VILLAAMIL \\ Catedrático de Derecho Político \\ Universidad Nacional de Educación a Distancia
}

En la trayectoria adoptada por esta revista en sus últimos números, de publicar repertorios bibliográficos sobre temas específicos que se encuentren huérfanos de una bibliografía mínimamente completa y actualizada, insertamos a continuación una referencia bibliográfica sobre el Derecho electoral español y la práctica de las elecciones en nuestra patria durante el ancho y azaroso lapso de tiempo que va desde 1810 hasta 1936. Materia esta de estudio sobre la que, si no recordamos mal, no se había recopilado hasta el presente una bibliografía mínimamente extensa.

El recopilador quiere advertir expresamente que este repertorio no tiene ambición de exhaustividad y es más bien el índice de algunos materiales de trabajo por él mismo reunidos de un tiempo a esta parte para fraguar un extenso trabajo sobre esta temática que, con la lentitud que le imponen otras obligaciones, tiene en proceso de elaboración.

Asimismo, el autor espera editar en breve una colección de leyes y otras normas electorales, en el período temporal de referencia, debidamente anotadas y concordadas y completadas con varios índices, que tiene terminada y a punto de publicación.

Aguado Arnal, Francisco: Jurisprudencia electoral del Tribunal Supremo, 1910-1916. Madrid, 1920.

Aguilo Lucía, Luis: Las elecciones en Valencia durante la Segunda República. Cátedra Fadrique Furio Ceriol, Facultad de Derecho de Valencia, Valencia, 1974.

- Sociología electoral valenciana (1903-1123). Cátedra Fadrique Furio Ceriol, Facultad de Derecho de Valencia, Valencia, 1976.

ALBERTI, Santiago: El republicanisme catalá i la restauració monárquica (1875-1923). Alberti editor, Barcelona, 1972.

Alcalá Galtano, Antonio: Lecciones de Derecho político constitucional. Imprenta de D. I. Boix, Madrid, 1843.

Alcalá Zamora, Niceto: Los defectos de la Constitución de 1931. Imp. de R. Espinosa, Madrid, 1936.

- Discurso pronunciado en el Congreso de los Diputados el día 20 de abril de 1914 sobre la conducta electoral del Gobierno. Imp. y Est. de la Prensa, Madrid, 1914. 
Alcántara Sáez, Manuel: Antología del pucherazo, en «Historia», abril de 1977, páginas 137-144.

Aller, Domingo Enrique: Exposición elemental teórico-bistórica del Derecho político. Librería de Victoriano Suárez, Madrid, 1875.

Alvarez-Gendín, Sabino: Las Cortes españolas. Tall. Tip. La Cruz, Oviedo, 1947. Alzaga, Oscar: El Partido Social Popular Español ante la problemática de la representación política, en «Boletín Informativo de Ciencia Política», núm. 10, agosto de 1972 , págs. 69-90.

- La primera democracia cristiana en España. Ariel, Barcelona, 1973.

ANónimo: Discurso sobre la introducción del gobierno representativo en España. Madrid, 1823.

ANónImo: Forma de las antiguas Cortes de Castilla con algunas observaciones sobre ellas encaminadas a demostrar que el texto literal de nuestras antiguas Cortes condena manifiestamente las teorias de la Soberania Nacional o de las Cortes meramente populares y del poder legislativo de las Cortes con el Rey. 1829.

ANónIMo: Sobre las ciudades y villas con voto en Cortes, en «Revista de Archivos, Bibliotecas y Museos», vol. 9.

Arcos, Santiago: $A$ los electores de diputados para las próximas Cortes constituyentes. Imprenta de la Gaceta de los Caminos de Hierro, Madrid, 1868.

ARgüelles, Agustín de: Examen bistórico de la reforma constitucional que bicieron las Cortes Generales y Extraordinarias desde que se instalaron en la Isla de León el dia 24 de septiembre de 1810 basta que cerraron en Cádiz sus sesiones en 14 del propio mes de 1813. Tomos I y II, Imprenta de Carlos Wood e Hijo, Londres, 1835.

Argüelles, Agustín: La reforma constitucional de Cádiz. Iter Ediciones, Madrid, 1970.

Artola, Miguel: La burguesía revolucionaria (1808-1869). Alianza Editorial, Madrid, 1973.

- Los orígenes de la España contemporánea. Instituto de Estudios Políticos, Madrid, 1959.

- Partidos y programas politicos (1808-1936). Tomos I y II, Aguilar, Madrid, 1974, 1975.

Azcárate, Gumersindo de: El régimen parlamentario en la práctica. Sobrinos de la sucesora de M. Minuesa de los Ríos, Madrid, 1931.

Azonín: Parlamentarismo español (1904-1916), en Obras completas, tomo III, Aguilar, Madrid, 1947.

Barriobero y Herrán, E.: De Cánovas a Romanones (la bancarrota nacional). Apuntes para el estudio de algunos de nuestros problemas actuales. Imp. A. Marzo, Madrid, 1916.

Bentto y Endara, Lorenzo: La rebabilitación del caciquismo. Conferencia, Madrid, 1930.

Benoist, Charles: Cánovas del Castillo. Ed. Literarias, Madrid, 1931.

Bentham, Jeremias: Consejos que dirige a las Cortes y al pueblo español. Repullés, Madrid, 1820.

Bergua Olavarrieta, Juan B.: Legislación electoral. Sáez Hermanos, Madrid, s. f. Bertelsen RepetTo, Rául: El Senado en España. Inst. de Estudios Administrativos, Madrid, 1974.

Bofarull y Romaña, Manuel: Las antiguas Cortes. El moderno Parlamento. El régimen representativo orgánico. Alcalá de Henares, 1945.

BöHL DE FABER, Cecilia (Fernán Caballero): Fisonomía natural y política de los procuradores en las Cortes de 1834, 1835 y 1836. Imp. de Ignacio Boix, Madrid, 1836. 
- Resultados de las últimas elecciones para diputados y senadores. Imp. de Eusebio Aguado, Madrid, 1837.

BoNilla y SAN MARTín, Adolfo: La crisis de la soberanía nacional y el fantasma de la representación parlamentaria. (Discurso leído en la Real Academia de Jurisprudencia y Legislación el día 12 de abril de 1916.) Establecimiento Tip. de Jaime Raté, Madrid, 1916.

BoRREgo, Andrés: La democracia indígena y la democracia de relumbrón. Imp. de García y Caravera, Madrid, 1881.

- A los electores de la provincia de Málaga.

- El libro de las elecciones. Reseña bistórica de las verificaciones durante los tres periodos del régimen constitucional (1810-1814, 1820-1823, 1834-1873). Extractado de «La Brújula», revista semanal, Imp. Española, Madrid, 1874.

- Ensayo sobre los partidos políticos en España. Est. Tip. de E. Viota, Madrid, 1884.

- Manual electoral para el uso de los electores de la opinión monárquico-constitucional. Imp. de la Compañía Tipográfica, Madrid, 1837.

- Misión y deberes de las clases conservadoras bajo la monarquía democrática. Madrid, 1872.

- De la organización de los partidos en España considerada como medio de adelantar la educación constitucional de la nación y de realizar las condiciones del gobierno representativo. Anselmo Santa Coloma, editor, Madrid, 1855.

- Principios constituyentes aplicables a la reforma de los abusos, bijos del atraso de nuestra educación política, y exposición de la legislación apropiada a preparar una organización conforme a los intereses y al carácter de la nación. Tip. de Gregorio Estrada, Madrid, 1876.

- Lo que ba sido, lo que es y lo que puede ser el partido conservador. Imp. de M. Ribadeneyra, Madrid, 1857.

- La Restauración (estudio político). Imp. Española, Madrid, 1875.

- La torre de Babel en estado de construcción por obra común de los partidos políticos españoles. Imp. Barrio y García, Madrid, 1890.

Brenan, Gerald: El laberinto español. Ruedo Ibérico, París, 1962.

Сасно ZaBalza, Antonio: Las últimas elecciones de la República. La Unión Militar Española.

Calvo Marcos, Manuel: Régimen parlamentario de España en el siglo XIX. Apuntes y documentos para su bistoria. Establecimiento Tip. de El Correo, Madrid, 1883.

Capel Martínez, Rosa M.a : El derecho electoral femenino, en «Historia», abril de 1977, págs. 33-49.

Carnicero, José Clemente: Examen crítico de la Constitución de Cádiz de 1812, de la teoría de las Cortes de Marina y de otras obras. Madrid, 1830.

CARR, Raymond: España 1808-1939. Ariel, Barcelona, 1968.

CARTA: Que el célebre jurisconsulto y hábil publicista Jeremias Bentham dirigió a los españoles en el año 1822 sobre la reforma proyectada en nuestra Constitución para establecer una Cámara Alta. Cádiz, 1837.

Cascales MuÑoz, José: El problema político al inaugurarse el siglo XX. El régimen parlamentario y el funcionalismo. Librería de Victoriano Suárez, Madrid, 1902.

Cascales Ramos, Antonio: Otoño electoral. Planeta, Barcelona, 1974.

CASEs MéndeZ, José Ignacio: La elección de 22 de septiembre de 1837, en «Revista de Estudios Políticos», núm. 212, marzo-abril de 1977, págs. 167-215.

CASES, José Ignacio: El sufragio censitario, en «Historia», abril de 1977, págs. 51-60.

- El sufragio universal, en «Historia», abril de 1977, págs. 61-73. 
Castro, Concepción de: Andrés Borrego. Periodismo liberal conservador (18301846). Miguel Castellote, editor, Madrid, 1972.

Catecismo del Interventor y del Apoderado, por «E1 Alcalde», Madrid (s. a. 1921).

Cervera, Valerio: La regeneración por el sufragio. Imp. de José Tous, Palma de Mallorca, 1899.

Cinrva, Juan de la: Las elecciones municipales de diciembre de 1909 en Murcia y en el distrito de Mula. Documentos que acreditan la intervención que en ellas tuvieron las autoridades gubernativas. Imp. Alemana, Madrid, 1910.

Cillán Apalategur, Antonio: Elecciones a diputados provinciales en Guipúzcoa el año 1911, en «Historia», abril 1977, págs. 121 a 127.

Clara, José: Las elecciones de 1869 a Girona. Rafael Dalman, Barcelona, 1974.

Colección de leyes discutidas por las Cortes y sancionadas por el Rey, correspondientes a la legislatura de 1876. Ed. Oficial, Madrid, 1877.

ColmeIro, Manuel: Curso de Derecho político, según la bistoria de León y Castilla. Imp. de Fermín Martínez García, Madrid, 1873.

- Elementos del Derecho Político y Administrativo en España. Lib. de Angel Calleja, Madrid, 1858.

Collins, Herbert. R.: Political campaign torches. Smithsonian Institution, Washington, 1964.

Comellas, José Luis: Los moderados en el poder (1844-1854). C. S. I. C., Madrid, 1970.

Conferencia electoral. Multicopista Villarroel, Barcelona, 1967.

Congreso DE los Diputados: Constituciones y reglamentos. Ramón Velasco, Madrid, 1931.

- Leyes electorales y proyectos de ley. Imp. Hijos de J. A. García, Madrid, 1906.

- Organización y funcionamiento de las Cortes según las Constituciones españolas y reglamentación de dicho cuerpo colegislador. (Exposición sintética por Adolfo Pons y Umbert.) Hijos de M. G. Hernández, Madrid, s. f.

- Reglamento del Congreso de los Diputados. Imp. del Colegio de Sordomudos, Madrid, 1838.

- Leyes electorales y proyectos de ley. Madrid, 1906.

- Leyes electorales. Ley de incompatibilidades. Suc. de Rivadeneyra, Madrid, 1933.

- Dictámenes sobre interpretación constitucional. Madrid, 1936.

Cores Trasmonte, Baldomero: Sociología política de Galicia. Orígenes y desarrollo (1846-1936). Librigal, La Coruña, 1976.

CoRTES DE CÁDIZ: Complementos de las sesiones verificadas en la isla de León y en Cádiz. Extractos de las discusiones, datos, noticias, documentos y discusiones publicados en periódicos y folletos de la época, por don Adolfo de Castro. Tomo I. Imprenta de P. Pérez de Velasco, Madrid, 1913.

Cortés, Donoso: Obras completas. Tomos 1 y 2, B. A. C., 1970, Madrid.

CoRtés Domínguez, José: Bases para una ley electoral redactada por el candidato derrotado en las elecciones para Diputados a Cortes de 1893. M. Romero, Madrid, 1901.

Costa y Martínez, Joaquín: Oligarquía y caciquismo como la fórmula actual de gobierno en España. Úrgencia y modo de cambiarla. Imp. de Hijos de Hernández, Madrid, 1902.

CotTERET, Jean Marie: Los sistemas electorales. Barcelona, 1973.

Cuadra, Agustín María de la: Principios de Derecho político acomodados a la enseñanza de las Universidades y seguidos de un ligero comentario a la Constitución actual de España. Imp. de F. Lis y Vázquez, Sevilla, 1853.

Cuco Giner, Alfonso: El valencianismo político (1878-1936). Garbí, Valencia, 1971. 
CuE, Gloria: Las elecciones sindicales, en «Historia», abril de 1977, págs. 95-108. Cuenca Toribio, José María: Estudios sobre la Sevilla liberal (1812-1814). Anales de la Univ. Hispalense, Sevilla, 1973.

Cuesta, Salvador: Elementos de Derecho político. Imp. de F. Núñez, Salamanca, 1877.

Charbonnier, J.: Organisation électorale et répresentative de tous les pays civilisés. Librairie de Guillammin et Ge, París, 1883.

Derecho electoral vigente: segunda edición de la obra titulada «La última ley electoral para diputados a Cortes y concejales de 8 de agosto de 1907». Hijos de J. A. García, Madrid, 1909.

Derozier, Albert: Les discussions sur la loi électorales espagnole en 1835 et en 1836, le gouvernment en échec. 1965.

Díez del Corral, Luis: El liberalismo doctrinario. Inst. de Est. Pol., 2. a ed., Madrid, 1956.

Un diputado y sus electores: viaje de D. Eleuterio Delgado Martín. Biblioteca del Boletín de Tabacos y Timbre, Madrid, 1902.

Los diputados americanos en las Cortes españolas. Los diputados de Puerto Rico 1872-1873. Madrid, 1880.

Los diputados pintados por sus bechos. Biografía de D. Rafael Carrillo y Gutiérrez, diputado de Almería en la Asamblea constituyente de 1869. Imp. de R. Labajos, Madrid, 1869.

Los diputados pintados por sus bechos: colección de estudios biográficos 1869-1870. 2 vols.

Los diputados provinciales interinos a sus administrados (Alvarez Estrada, Marqués de Camarines, Arriaga y Gutiérrez...). Imp. R. Velasco, Madrid, 1901.

Durán, J. A.: Historia de caciques, bandos e ideologías en la Galicia no urbana. Siglo Veintiuno de España, editores, Madrid, 1972.

Duverine, A.: Cuadro bistórico de los abusos y espiritu de reforma política en España. Boix, editor, Madrid, 1840.

La elección de un alcalde. Pieza cómica, Cádiz, 1849.

Elección de senador por las sociedades económicas de Andalucía y Canarias. Escrito de impugnación presentado ante la Comisión de Actas del Senado. Imp. de M. Alvarez, Cádiz, 1921.

Las elecciones. Coloquio a la plebe por un labriego. Imp. Luis Cases, Madrid, 1839.

Las elecciones. Sus vicios, la influencia moral del gobierno. Estadistica de la misma $y$ proyecto de reforma electoral. 1863.

Elecciones de 1858: exposición, protestas y documentos para acreditar la nulidad de las elecciones del distrito de Carrión de los Condes, en la provincia de Palencia. Tip. La Independencia Española, Madrid, 1858.

Elecciones de concejales y diputados provinciales. Madrid, 1897.

Elecciones de concejales y diputados provinciales. Madrid, 1905.

Elecciones de diputados a Cortes, senadores, diputados provinciales y concejales. Madrid, 1890.

Elecciones en Játrva, Unas: Establecimiento Tip. de El Correo, Madrid, 1887.

Las elecciones municipales: legislación aplicable a las elecciones para concejales según la Ley de Bases de Régimen Local de 17 de julio de 1945. Barcelona ( ¿1948?).

Elecciones municipales: recopilación de normas para su celebración, complementadas con el texto vigente de la Ley electoral, por la redacción de la «Administración práctica». Bayer Hnos. y Cía., Barcelona, 1957.

Elecciones municipales. Legislación. Valbuena, Madrid, 1960.

Elecciones provinciales... por D. Juan Bautista Catalá y Gavilá. Madrid, 1911. 
Elecciones de todas clases, o sea, de diputados a Cortes, senadores, diputados provinciales y concejales. $4 .^{a}$ ed., Madrid, 1898.

ENGELs, Marx: Revolución en España. Ariel, Barcelona, 1973.

Equipo dE Sociología Electoral, Barcelona: Las elecciones franquistas en Barcelona, en «Historia», abril de 1977, págs. 129-136.

La España del siglo XIX. Colección de conferencias históricas celebradas durante el curso de 1885-1886. Tomos I y II, Libería de D. A. San Martín, Madrid, 1886.

Estudios sobre la República II española (selección y presentación por Manuel Ramírez). Tecnos, Madrid, 1975.

EzA, Vizconde de: La representación proporcional. (Notas ampliadas de la conferencia dada el día 22 de enero de 1912 ante la Juventud Conservadora de Madrid.) Imprenta de Bernardo Rodríguez, Madrid, 1912.

Fernández Almagro, Melchor: Historia política de la España contemporánea. 2 vols., Ediciones Pegaso, Madrid, 1959.

- Las Cortes del siglo XIX y la práctica electoral, en «Revista de Estudios Políticos», vol. V, mayo-agosto de 1943, págs. 383-416.

- Historia política de la España contemporánea. Tomo I (1863-1885), tomo II (1885-1897), tomo III (1897-1902), Alianza Editorial, Madrid, 1968, 1970.

- Historia de la República española (1931-1936). Biblioteca Nueva, Madrid, 1940.

- Orígenes del régimen constitucional en España. Labor, Barcelona, 1928.

Fernández Carvajal, Rodrigo: El pensamiento español en el siglo XIX, en Historia general de las literaturas bispánicas, IV, segunda parte, págs. 342-366, Ed. Barna, Barcelona, 1957.

FERNÁNDEZ DE Los Ríos, A.: Estudio bistórico de las lucbas politicas en la España del siglo XIX. Tomos I y II, English y Gras, editores, Madrid, 1880.

Fernández Villaverde, Raimundo: Consideraciones bistórico-críticas acerca del sufragio universal como órgano de la representación politica en las sociedades modernas. (Discurso leído el 19 de mayo de 1889 en el acto de su recepción en la Real Academia de Ciencias Morales y Políticas.) Tip. de Manuel G. Hernández, Madrid, 1889.

- El sufragio universal. (Discurso leído en su recepción pública ante la Real Academia de Ciencias Morales y Políticas el 19 de mayo de 1889.) Tip. de M. G. Hernández, Madrid, 1889.

Ferrán, Ignacio María de: Extracto metódico de un curso completo de Derecbo político y administrativo. Librería de Juan Bastinos e Hijo, Barcelona, 1873.

FERrando Badía, Juan: La primera República española. Cuadernos para el Diálogo, Madrid, 1973.

FERrer y Fores, Ramón: La delincuencia en España. 1914-1915.

Figueroa y Torres, Alvaro de: Las responsabilidades politicas del antiguo régimen. De 1875 a 1923. Renacimiento, Madrid, s. f.

Figueroa, Alvaro de (Conde de Romanones): Vida municipal. (Discurso leído en el acto de su recepción en la Real Academia de Ciencias Morales y Políticas.) Imp. Renacimiento, Madrid, 1916.

Flórfz Estrada, Alvaro: En defensa de las Cortes. Miguel Castellote, editor, Madrid, 1973.

GamonedA, Antonio: Leyes electorales y proyectos de ley. Congreso de los Diputados, Imp. Hijos de J. A. García, Madrid, 1906.

García Escuder, José Matía: Medio siglo de bistoria española, en «Arbor», t. XV, XVI, enero-agosto de 1950.

García Gallego, Jerónimo: El régimen constitucional, la soberanía de la nación y el Estatuto del porvenir. Ed. Seráfica, Vich, 1928. 
García Huidobro, Elías: Las Cortes de Cádiz y las elecciones de los diputados de Chile, en «Rev. Chilena de Historia y Geografía», t. IV, 1912.

García Mercadal, José: Ideario de Joaquín Costa (textos escogidos y ordenados), Afrodisio Aguado, Madrid, 1964.

García Nieto, M. a Carmen; Donezar, Javier M., y López Puerta, Luis: Crisis del sistema canovista 1898-1923. Guadiana de Publicaciones, Madrid, 1972.

- Liberalismo democrático (1868-1874). Guadiana de Publicaciones, Madrid, 1971.

- Moderados y progresistas (1833-1868). Guadiana de Publicaciones, Madrid, 1971.

- Restauración y desastre 1874-1898. Guadiana de Publicaciones, Madrid, 1972.

- Revolución y reacción 1808-1833. Guadiana de Publicaciones, Madrid, 1971.

García Ruiz, Eugenio: Historias. Tomos I y II, Imprenta de E1 Pueblo Español, Madrid, 1876.

- Los siete artículos capitales, o sea, la democracia gobernando. Imprenta Española, Madrid, 1872.

García SAN Miguel, Julián: La representación parlamentaria, el sufragio obligatorio y el referéndum. (Discurso leído el 23 de junio de 1907 en su recepción pública en la Real Academia de Ciencias Morales y Políticas.) Establecimiento Tip. de Jaime Ratés, Madrid, 1907.

García SAN MigueL, Luis: De la sociedad aristocrática a la sociedad industrial en la España del siglo XIX. Cuadernos para el Diálogo, Madrid, 1973.

García Tejero, Alfonso: Historia político-administrativa de Mendizábal dedicada al pueblo liberal español. Tomos I y II, Est. Tip. de J. A. Ortigosa, Madrid, 1858.

García Venero, Maximiano: Antonio Maura 1907-1909. Ediciones del Movimiento, Madrid, 1953.

- Eduardo Dato. Vida y sacrificio de un gobernante conservador. Diputación Foral de Alava, Vitoria, 1969.

- Historia del parlamentarismo español (1810-1833). Instituto de Estudios Po. líticos, Madrid, 1946.

- Melquiades Alvarez. Historia de un liberal. Prólogo de Azorín, Editorial Alhambra, Madrid, 1954.

- Santiago Alba. Cincuenta años de bistoria política española. Aguilar, Madrid, 1963.

Garrido Falla, Fernando: Leyes políticas de España. «Boletín Oficial del Estado», Madrid, 1969.

Garrorena Morales, Angel: El Ateneo de Madrid y la teoria de la monarquía liberal (1836-1847). Instituto de Estudios Políticos, Madrid, 1974.

Germán, Luis G.: Zaragoza 1933: de la abstención a la insurrección, en «Historia», abril de 1977, págs. 109-113.

Gil Novales, Alberto: Las sociedades patrióticas (1820-1823). Tomos I y II, Tecnos, Madrid, 1975.

Gil y Robles, Enrique: El absolutismo y la democracia. Imp. Católica Salmanticense, 2. ${ }^{\mathrm{a}}$ ed., Salamanca, 1892.

- Tratado de Derecbo político. Imp. Católica Salmanticense, Salamanca, 1899.

GIL-Robles, José María: Discursos parlamentarios. Taurus, Madrid, 1971.

- No fue posible la paz. Ariel, Barcelona, 1968.

GINEBRA, Viriato: Opinión y Parlamento: observaciones en torno al sistema democrático parlamentario y al procedimiento electoral. Horizonte, S. A., Madrid, 1935.

GIRón, José: Asturias ante las elecciones de la II República, en «Historia», abril de 1977, págs. 115-120.

- Un estudio de sociología electoral: la ciudad de Oviedo y su contorno en las elecciones generales de 1933, en Sociedad politica y cultura en la España de los siglos XIX y XX. Cuadernos para el Diálogo, Madrid, 1973. 
Gobierno y las CoRtes del Estatuto, el: Materiales para su historia. Imprenta de Yenes, Madrid, 1837.

Goicochea y Cosculluela, Antonio: La crisis del constitucionalismo moderno. Editorial Voluntad, Madrid, 1925.

- Problemas del día (mosaico de conferencias, discursos y artículos). Madrid, 1916.

Gómez Aparicio, Pedro: Historia del periodismo español. Desde la «Gaceta de Madrid» (1661) basta el destronamiento de Isabel II. Editora Nacional, Madrid, 1967.

GÓmEz ImAz, Manuel: Los periódicos durante la Guerra de la Independencia (1808-1814). Tip. de la Rev. de Arch., Bibl. y Museos, Madrid, 1910.

González Carreño, Genaro: Caciquismo y caciques. Imp. y Lib. de Abundio Z. Menéndez, Palencia, 1917.

González Casandua, J. A.: Elecciones en Barcelona (1931-1936). Tecnos, Madrid, 1969.

GonzÁlez SeAra, Luis: Materiales para la sociología electoral de la Restauración, en «Anales de Sociología», núm. 2, 1966, págs. 182-213.

Guerrero, Paulette: El caciquismo en la provincia de Granada, en Sociedad política y cultura en la España de los siglos XIX y XX. Cuadernos para el Diálogo, Madrid, 1973.

Guimera Peraza, Marcos: Los diputados doceañistas canarios. Ala de Cultura, Tenerife, 1967.

Hennessy, C. A. M.: La República Federal en España. Aguilar, Madrid, 1967.

HeRnÁNDEZ Lafuente, Adolfo: El sufragio en la II República, en «Historia», abril de 1977, págs. 75-84.

HeRmet, Guy: Religión y urnas en España, en «Historia», núm. 4, agosto de 1976, páginas 35-41.

HerR, Ricard: España y la revolución del siglo XVIII. Aguilar, Madrid, 1973.

Hostos, Eugenio M. de: Lecciones de Derecho constitucional. Librexía Paul Ollendorff, París, 1908.

IVORRA LIMORTE, J. A.: El origen del derecho de asociación política en España. Cátedra Fadrique Furio Ceriol. Facultad de Derecho de Valencia, Valencia, 1974.

JANKE, Peter: Mendizábal y la instauración de la monarquía constitucional en España (1790-1853). Siglo XXI de España Editores, S. A., Madrid, 1974.

JIMÉNEZ dE Gregorio, Fernando: La convocación de Cortes constituyentes en 1810. Estado de la opinión española en punto a la reforma constitucional, en «Revista de Estudios de Historia Moderna», núm. V, Barcelona, 1955, págs. 223-347.

Junta Municipal del Censo Electoral: Guía electoral. Casa Provincial de Caridad, Barcelona, 1960.

JuRetschKe, Hans: Concepto de Cortes a comienzos de la Guerra de la Independencia, carácter $y$ actualización, en «Revista de la Universidad de Madrid», vol. IV, núm. 15, 1955, págs. 369-405.

- Supuestos bistóricos e ideológicos de las Cortes de Cádiz, en «Nuestro Tiempo», año II, núm. 18, diciembre de 1955, págs. 13-35.

- Vida, obra y pensamiento de Alberto Lista. CSIC, Madrid, 1951.

Jutglar, Antoni: Pi y Margall y el federalismo español. Tomos I y II, Taurus, Madrid, 1975, 1976.

Kiernan, V. G.: La Revolución de 1854 en España. Aguilar, Madrid, 1970.

LABra, Rafael M.a de: La reforma electoral en las Antillas españolas. (Discursos pronunciados en el Congreso de los Diputados de España en marzo y abril de 1890.) Imp. y Estereotipia de «E1 Liberal», Madrid, 1891.

LARrA, Mariano José de: (Fígaro) Dios nos asista (tercera carta de Fígaro a su corresponsal en París). Imp. de Repullés, Madrid, 1836. 
Legislación electoral: ordenadas, concordadas y anotadas por E. Barriobero y Herrán. Gab. Sáez, Madrid, 1931.

Legislación electoral para diputados a Cortes y concejales. Gráfica Socialista, Madrid, s. f.

Legislación electoral para diputados a Cortes y concejales, senadores $y$ diputados provinciales. Madrid, 1908.

Legislación electoral para diputados a Cortes y concejales. Con notas, apéndice e índices por la redacción de la «Revista de Tribunales». J. Góngora, 3.a ed., Madrid, 1920.

Legislación electoral relativa a diputados a Cortes, concejales, Tribunal de Garantías y Providencia de la República. Madrid, 1933.

Legislación electoral española. Anotaciones y concordancias. Ministerio de la Gobernación, Madrid, 1970.

Legislación electoral española. Actualización a 20 de septiembre de 1971. Secretaría General Técnica del Ministerio de la Gobernación, 2 vols., Madrid, 1971.

Ley electoral vigente. Edit. Emilio García Enciso, Pamplona, 1936.

Ley electoral con los últimos decretos y disposiciones de la República publicados por la «Gaceta de Madrid». Decretos de 28 de julio, 9 de octubre de 1933. Ley de 27 de julio de 1933 y 8 de agosto de 1907. (S. 1., s. i., s. f.)

Ley electoral de 1837. (S. f., s. ed.)

Ley electoral (de 18 de julio de 1865). Imp. de Manuel Galiano, Madrid, 1865.

Ley electoral y disposiciones posteriores. Edición municipal, Tip. de los Asilos de S. Bernardino, Madrid, 1871.

Ley electoral de 1870 . (S. f., s. ed.)

Ley electoral de 20 de agosto de 1870 y leyes de 1 de enero de 1871 sobre la incompatibilidad del cargo de diputado con el ejercicio de destinos públicos. Imp. Enrique de la Riva, Madrid, 1871.

Ley electoral de 20 de agosto de 1870. E. de la Riva, 2. ${ }^{a}$ ed., Madrid, 1877.

Ley electoral para el nombramiento de diputados a Cortes. Imp. Nacional, Madrid, 1846.

Ley electoral para diputados a Cortes. Continuación del cuaderno núm. 6 correspondiente a la guía legislativa de gobernación que publica... Gerónimo Flores y López. Alejandro Guerrero, Cádiz, 1877.

Ley electoral para el nombramiento de diputados a Cortes. Madrid, 1848.

Ley electoral. Madrid, 1865.

Ley electoral... (de 23 de junio de 1870). Madrid, 1870.

Ley electoral para senadores de 8 de febrero de 1877 con fórmulas... por don Juan Bautista Catalá y Gavilá. Madrid, 1910.

Ley electoral decretada en 28 de diciembre de 1878. Imp. Nacional, Madrid, 1878.

Ley electoral para diputados a Cortes en la península de 26 de junio de 1890. Madrid, 1890.

Ley electoral para diputados a Cortes y concejales de 8 de agosto de 1907. Imp. Municipal, Madrid, 1916.

La última ley electoral para diputados a Cortes... de 8 de agosto de 1907. Madrid, 1907.

Ley electoral de diputados a Cortes de 8 de agosto de 1907 completada y comentada por la redacción de «El Consultor de los Ayuntamientos». 8. ${ }^{\mathrm{a}}$ ed., Madrid, 1909.

Ley electoral de diputados a Cortes y de concejales de 8 de agosto de 1907. 2. ${ }^{\mathrm{a}}$ ed., Madrid, 1909.

Novísima ley electoral para diputados a Cortes de 8 de agosto de 1907. Madrid, 1910. 
Ley electoral para diputados a Cortes de 8 de agosto de 1907. Comentada por don Julián Bautista Catalá y Gavilá. 2. a ed., Madrid, 1911.

Ley electoral de diputados a Cortes de 1907 comentada por la redacción de «El Consultor de los Ayuntamientos». 11. a ed., Madrid, 1916.

Ley electoral para diputados a Cortes. Sancionada el 8 de agosto de 1907. Madrid, 1918.

Ley electoral de diputados a Cortes de 8 de agosto de 1907. 12 ed., Madrid, 1919.

Ley electoral de diputados a Cortes de 8 de agosto de 1907 comentada por la redacción de «El Consultor de los Ayuntamientos». 13 ed., Madrid, 1922.

Ley electoral de diputados a Cortes y de concejales de 8 de agosto de 1907 comentada por la redacción de «El Consultor de los Ayuntamientos». (Imp. de «El Consultor»), 14 ed., Madrid, 1931.

Ley electoral de diputados a Cortes de 8 de agosto de 1907 comentada por la redacción de «El Consultor de los Ayuntamientos». 14 ed., Madrid, 1936.

Ley electoral de diputados a Cortes y de concejales de 8 de agosto de 1907 comentada por la redacción de «El Consultor de los Ayuntamientos y de los Juzgados Municipales». Imp. de «El Consultor», 15 ed., Madrid, 1936.

Ley electoral de 8 de agosto de 1907 complementada con las disposiciones dictadas basta noviembre de 1945. Tip. Flórez, 16 ed., Madrid, 1945.

Ley electoral para diputados a Cortes y concejales anotada adaptado a ella el Decreto... de 8 de mayo de 1931 para elecciones de Cortes constituyentes por don F. López de Goicoecbea y don Pedro Martínez Cayuela. Gráficas Reunidas, Madrid, 1931.

Ley electoral para diputados a Cortes constituyentes de 1931. Madrid, 1931.

Ley electoral del Senado. V. Sáiz, Madrid, s. f.

Leyes electorales municipal y provincial publicadas en el suplemento de «La Gaceta» de 21 de agosto de 1870. Toledo, 1870.

Leyes electorales, municipal y provincial de 1870. Imp. de J. Fernández, Madrid, 1870.

Leyes electorales municipales y provinciales de 20 de agosto de 1870. Madrid, 1876.

Extracto de las leyes electorales vigentes para las elecciones de concejales, diputados a Cortes, senadores. Tip. de F. de P. Díaz, Sevilla, 1911.

Leyes electorales o sufragio universal. Madrid, 1890.

Leyes electorales de diputados a Cortes y senadores. 2.a ed., Madrid, 1891.

Leyes electorales para diputados a Cortes, senadores, concejales y diputados provinciales por el Municipio. Madrid, 1897.

Leyes electorales de diputados a Cortes. 4. ${ }^{\mathrm{a}}$ ed., Madrid, 1898.

Leyes electorales para diputados a Cortes y senadores en 1901. Madrid, 1901.

Leyes electorales de diputados a Cortes y senadores. 5. ${ }^{\mathrm{a}}$ ed., Madrid, 1905.

Leyes electorales de diputados a Cortes y concejales de 8 de agosto de 1907. Madrid, 1907.

Leyes electorales para diputados a Cortes, concejales $y$ diputados provinciales de 8 de agosto de 1907 y R. D. de adaptación de 9 de septiembre de 1909 concordadas $y$ anotadas por el alcalde de Madrid. (S. f.)

Leyés electorales para diputados a Cortes y concejales de 8 de agosto de 1907. Madrid, 1909.

Leyes electorales para senadores de 8 de febrero de 1877, para diputados a Cortes $y$ concejales de 8 de agosto de 1907. 2. ${ }^{\mathrm{a}}$ ed., Madrid, 1913.

Linz, Juan, y Miguel, J. M. de: Un análisis regional de las elecciones de 1936, en «Revista Española de la Opinión Pública», núm. 48, abril-junio de 1977.

Linz, Juan J.: El sistema de partidos en España. Narcea, S. A., Ediciones, Madrid, 1967. 
López Nieto, Lourdes: Polémicas sobre la geografía electoral, en «Historia», abril de 1977, págs. 11-21.

MAckIE, Thomas T.: The international almanac of electoral bistory. Mac Millan, Londres, 1974.

Madariaga, Salvador de: España. Ensayo de bistoria contemporánea. Ed. Sudamérica, 7. ${ }^{\text {a }}$ ed., Buenos Aires, 1964.

Madrazo, Francisco: Las Cortes españolas; resumen bistórico de las tres épocas parlamentarias. Imp. de D. A. Babia, Madrid, 1857.

Malatesta, Enrico: En tiempo de elecciones. El absurdo político. Edic. de la «Revista Blanca», 7. ${ }^{\text {a }}$ ed., Barcelona, 1936.

Maravall, José Antonio: El pensamiento político español a comienzos del siglo XIX: Martínez Marina, en «Revista de Estudios Políticos», núm. 81, mayojunio de 1955.

MARTín, Teodoro: La desamortización. Textos político-jurídicos. Narcea, S. A., Ediciones, Madrid, 1973.

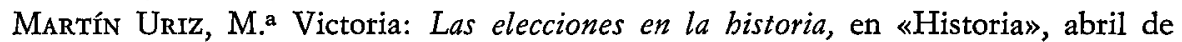
1977, págs. 156-162.

Martínez Cayuela, Pedro: Ley electoral para diputados a Cortes y concejales, anotada, completada y adoptada a ella el decreto del Gobierno provisional de la República de 8 de mayo de 1931 para la elección de Cortes constituyentes.

Martínez Cuadrado, Miguel: La burguesia conservadora (1874-1931). Alianza Universidad. Historia de España, Alfaguara VI, Madrid, 1973.

- Elecciones y partidos políticos de España (1868-1931). Tomos I y II, Taurus, Madrid, 1969.

- El retorno a la democracia, en «Historia», abril de 1977, págs. 145-155.

- Trayectoria del sufragio en España, en «Historia», abril de 1977, págs. 5-10.

Martínez Marina, Francisco: Discurso sobre el origen de la monarquía y sobre la naturaleza del Gobierno español. Instituto de Estudios Políticos, Madrid, 1957.

- Teoria de las Cortes o grandes juntas nacionales de los reinos de León y Castilla. 3 vols., Imprenta de D. Fermín Villalpando, Madrid, 1813.

Martínez RuIz, J.: Parlamentarismo español (1904-1916). Biblioteca Calleja, Madrid, 1921.

Martínez Sospedra, Manuel: Incompatibilidades parlamentarias en España (1810. 1936). Cátedra Fadrique F. Ceriol. Facultad de Derecho de Valencia, Valencia, 1974.

Massanet y Beltrán, J.: La reforma constitucional. Lo que se intenta y lo que debiera bacerse. Palma de Mallorca, 1929.

Maura, Antonio: Treinta y cinco años de vida pública. (Ideas políticas, doctrinas de Gobierno y campañas parlamentarias recopiladas por José Ruiz-Castillo Franco.) Biblioteca Nueva, Madrid, 1953.

Maura, Duque, y Fernández Almagro, Melchor: Por qué cayó Alfonso XIII. Ediciones Mabos Mundos, 2. ${ }^{\mathrm{a}}$ ed., Madrid, 1948.

Maura, Miguel: Así cayó Alfonso XIII. Ariel, 5.a ed., Barcelona, 1968.

Maura Gamazo, Gabriel: Historia crítica del reinado de Alfonso XIII. Tomos I y II, Barcelona, 1919-1925.

Memorias de don Antonio Alcalá Galiano, publicados por su hijo. Tomos I y II, Imprenta de Enrique Rubiños, Madrid, 1886.

Mesa de la Peña, Rafael: Antología de las Cortes de 1903 a 1907 arregladas por Rafael Mesa de la Peña según encargo del excmo. presidente del Congreso de los Diputados. Madrid, 1913. 
Mestre, Esteban: Delitos electorales en España (1864-1933). Ed. Zero, Madrid, 1970.

- Elecciones de 1858. Exposición, protestas y documentos para acreditar la nulidad de las elecciones del distrito de Carrión de los Condes, provincia de Palencia. Establecimiento de la Independencia Española, Madrid, 1858.

Mellado, Fernando: Tratado elemental de Derecbo político. Tip. de M. G. Hernández, Madrid, 1891.

Molas, Isidro: Lliga catalana (un estudio d'Estasiologia). Edicions 62, Barcelona, 1972.

- El sistema de partidos políticos en Cataluña (1931-1936). Ed. Península, Barcelona, 1974.

Moret y Prendergast, Segismundo: Dircurso leído el dia 9 de noviembre de 1895 en el Ateneo Científico y Literario de Madrid sobre el tema del referéndum. Esti. Ip. Sucesores de Ribadeneyra, Madrid, 1895.

- La representación nacional. Teoría del sufragio. (Conferencias pronunciadas en la Universidad Central.) Imp. de F. García Herrero, Madrid, 1884.

Muñoz Pellin, Javier: Antecedentes de la Ley electoral de 8 de agosto de 1907. Tesina de licenciatura (inédita). Facultad de Derecho. Universidad de Valencia, Valencia, 1975.

Murillo Ferrol, Francisco: Estudios de sociología política. Tecnos, Madrid, 1972.

- El manifiesto de los persas y los orígenes del liberalismo español, en Homenaje a don Nicolás Pérez Serrano. Tomo II, Instituto Editorial Reus, Madrid, 1959.

Navarro Amand, Mario: Estudios sobre procedimiento electoral, en «Revista de Legislación», Madrid, 1885.

Nido y Segalerva, Juan del: Historia política parlamentaria del excmo. señor don Antonio Cánovas del Castillo. Tipografías de Prudencio P. de Velasco, Madrid, 1914.

- Historia política y parlamentaria de s. a. don Baldomero Fernández Espartero. Imprenta de Ramona Velasco, viuda de Prudencio Pérez, Madrid, 1916.

Nieva, Josef María de: Decretos del Rey Nuestro Señor D. Fernando VII y de la Reina su Agusta Esposa. Tomo XVIII, Imprenta Real, Madrid, 1834.

- Decretos de la Reina Nuestra Señora, D. ${ }^{a}$ Isabel II, dadas en su Real Nombre por su Agusta Madre, la Reina Gobernanta. Tomos XIX, XX, XXI, Imprenta Real, Madrid, 1835, 1836.

O’donnell, Enrique: La democracia española. Imprenta de M. Minuesa, Madrid, 1858.

Oliva Marra-López, Andrés: Andrés Borrego y la política española del siglo XIX. Instituto de Estudios Políticos, Madrid, 1959.

ORTIZ DE BuRgos, José: La representación proporcional. Madrid, 1921-1923.

PABON, Jesús: Cambo. Tomo I: 1876-1918. Tomo II, parte primera: 1918-1930; parte segunda: 1930-1947. Ed. Alpha, Barcelona, 1952, 1969.

Pacheco, Joaquín Francisco: Lecciones de Derecho político constitucional pronunciadas en el Ateneo de Madrid en 1844 y 1845. Tomo I, Imp. y Lib. de Ignacio Boix, Madrid, 1845.

Pagndul, Anne-Marie: Ministere de l'Interieus Affaires electorales 1830-1919. Inventaire. Archive Generales du Royaume, Bruselas, 1972.

Pando Fdez. de Pinedo, Manuel (marqués de Miraflores): De la reforma de la Constitución de 1845 verificada en 1857 y del proyecto de ley proponiendo la supresión de sus artículos 18 y 20 de aquella reforma en 1863. Imprenta de D. A. Espinosa, Madrid, 1864.

- Discurso bistórico sobre las Cortes de España en los tres últimos siglos leído en 
la Real Academía de la Historia el 5 de julio de 1850. Imprenta de la Real Academia de la Historia, Madrid, 1850.

- Memorias para escribir la bistoria contemporánea de los siete primeros años del reinado de Isabel II. Tomo I, Imprenta de Ia Viuda de Calero, Madrid, 1843.

Pedrosa, Luis: Qué es la masonería. Ed. La Gaya Ciencia, Barcelona, 1977.

PÉrez GALDós, Benito: Artículo publicado sobre el panorama electoral en «Revista de España», tomo XXVII, julio-agosto, Madrid, 1872, págs. 555-562.

PÉreZ y Gómez, Antonio: Las elecciones a diputados en Cieza en 1910. (Con nueve cartas inéditas cruzadas entre don Juan de la Cierva y don Juan Pérez Martínez.) Sucesores de Nogués, Murcia, 1965.

Pérez Prendes, José Manuel: Cortes de Castilla y Cortes de Cádiz, en «Revista de Estudios Políticos», núm. 126, nov.-dic. de 1962.

Pérez Serrano, Nicolás: La Constitución española (9 de diciembre de 1931), antecedentes. Texto, comentarios. Editorial Revista de Derecho Privado, Madrid, 1932.

PÉRez Vilariño, J.: Inquisición y Constitución en España. Zero, S. A., Madrid, 1973.

Pi y Margall, Francisco: El reinado de Amadeo de Saboya y la República de 1873. (Prólogo y notas de Antoni Jutglar.) Seminarios y Ediciones, S. A., Madrid, 1970.

Pino Artacho, Juan del: Aspectos sociológicos-políticos del caciquismo español, en «Revista Española de la Opinión Pública», núm. 15, enero-marzo 1969, I. O.P.

Pons y UMBert, Adolfo: La crisis de la moral en nuestro régimen político. (Conferencia pronunciada el 11 de enero de 1916 en el Centro Maurista de Madrid.) Madrid, 1916.

- La opinión y los partidos. Estudio político, 3. ${ }^{a}$ ed. Imprenta de los Hijos de M. G. Hernández, Madrid, 1908.

Posada, Adolfo: La crisis del constitucionalismo. Discursos pronunciados en la Real Academia de Ciencias Morales y Políticas. Librería General de Victoriano Suárez, Madrid, 1925.

- Escritos municipalistas y de la vida local. Inst. de Estudios de Administración Local, Madrid, 1979.

- Estudios sobre el régimen parlamentario en España. Madrid, 1891.

- El sufragio según las teorías filosóficas y las principales legislaciones. Sucesores de M. Soler, Barcelona, s. a.

- Tratado de Derecbo Político. Tomos I y II. Librería General de Victoriano Suárez, Madrid, 1935.

Rama, Carlos María: La crise espagnole an $X X^{e}$ siècle. Libraire Fischbacher, París.

Ramírez Jiménez, Manuel: Los grupos de presión en la Segunda República. Tecnos, Madrid, 1969.

Ramos, Demetrio: Las Cortes de Cádiz y América, en «Revista de Estudios Políticos», núm. 126, nov.-dic. 1962.

Regla: Reglas de conducta para católicos. Documentos importantísimos. Imp. de la Revista de Arch. Bibl. y Museos, 1906.

Reparaz y Astein, Julián de: El referéndum. Hijos de Reus, Madrid, 1917.

Rrco y Amat, Juan: Historia politica y parlamentaria de España. Tomos I, II y III. Imprenta de las Escuelas Pías, Madrid, 1860-1861.

Ríos, Juan Miguel de los: Derecho político general español y europeo, 3 vols. Imprenta de don Ignacio Boix, Madrid, 1846.

RobInson, Richard A. H.: Los orígenes de la España de Franco. Derecha, República y revolución (1931-1936). Grijalbo, Barcelona, Buenos Aires, México, 1974. 
RuIz DE AzúA, Miguel A.: Las elecciones franquistas, en «Historia», abril 1977, págs. 85-94.

Ruiz Del Castillo, Carlos: Manual de Derecho Politico. Inst. Ed. Reus, Madrid, 1939.

SÁnchez de los Santos, Modesto: Las Cortes españoles. Las de 1907. Est. Tip. de Antonio Marzo, Madrid, 1908.

SÁnCHEZ Agesta, Luis: Historia del constitucionalismo español. Inst. de Estudios Políticos, Madrid, 1964.

- Orígenes, evolución y crisis del régimen constitucional, en La España de los años setenta. Vol. III: El Estado y la política, t. I. Ed. Moneda y Crédito, Madrid, 1974 , págs. $35-87$.

SÁNCHEZ GuERRA, José: La crisis del régimen parlamentario en España: la opinión y los partidos. Discurso leído en el acto de su recepción por el Excmo. Sr. D. José Sánchez Guerra y contestación del Excmo. Sr. D. Tomás Montejo y Rica, el día 3 de junio de 1923. Real Academia de Ciencias Morales y Políticas, Madrid, 1923.

SÁNCHEZ DE ToCA, Joaquín: El régimen parlamentario y el sufragio universal. Tipografía de M. G. Hernández, Madrid, 1889.

Sanmartín Puente, Manuel: Tratado de Derecho electoral español, 3 tomos. Reus, Madrid, 1931.

Santamaría de Paredes, Vicente: Curso de Derecbo político, 9.a ed. Librería de Fernando Fe, Madrid, 1913.

Santayana Bustillo, Lorenzo: Gobierno político de los pueblos de España. Instituto de Estudios de Administración Local, Madrid, 1979.

Seco Serrano, Carlos: Alfonso XIII y la crisis de la Restauración. Ariel, Barcelona, 1969.

Sedano y Arestarán, Carlos de: Ley electoral para diputados a Cortes, anotada por..., Madrid, 1890.

Sevilla Andrés, Diego: La Constitución española de 1812 y la francesa del 91, en Saitabi, VII, 1949, págs. 212-234.

- Constituciones y otras leyes y proyectos políticos de España, 2 tomos. Editora Nacional, Madrid, 1969.

- La guerra civil y la desorganización política (1931-1939), en La España de los años setenta. Vol. III: El Estado y la política, t. I. Ed. Moneda y Crédito, Madrid, 1974, págs. 93-141.

- Historia política de España (1800-1967). Editora Nacional, Madrid, 1968.

- Orígenes de la crítica social en España (1800-1856). Cátedra Fadrique Furio Ceriol, Facultad de Derecho, Valencia, 1975.

- Los partidos políticos españoles basta 1868. Tip. P. Quiles, Valencia, 1958.

Solana, Fermín: Historia parlamentaria del socialismo: Julián Besteiro. (Política

Solana, Fermín: Historia parlamentaria del socialismo: Julián Besteiro. [Política y legislaturas de la Monarquía (1918-1923).] Tomo I, Taurus, Madrid, 1975.

Soldevilla, Fernando: El año político de 1907. Imp. de Ricardo Rojas, Madrid, 1908.

Solís, Ramón: El Cádiz de las Cortes. Instituto de Estudios Políticos, Madrid, 1958.

Souto Naveira, Marcelino: Guía práctica electoral. Imp. Jean, Santander, 1966.

SuÁrez, Federico: La crisis política del antiguo régimen en España (1800-1840). Ediciones Rialp, Madrid, 1958.

SuÁrez Verdaguer, Federico: Conservadores, innovadores y renovadores en las postrimerias del antiguo régimen. Estudio General de Navarra, Pamplona, 1955.

- Donoso Cortés en el pensamiento europeo del siglo XIX. Ateneo, Madrid, 1954. 
- El régimen liberal español, en «Boletín de la Universidad de Santiago de Compostela», 1950, págs. 63-109.

TAPARELI, Luis: Examen crítico del gobierno representativo en la sociedad moderna. Tomos I y II. Imp. de El Pensamiento Español, Madrid, 1886.

Tomás Villarroya, Joaquín: El sistema político del Estatuto Real (1834-1836). Instituto de Estudios Políticos, Madrid, 1968.

- El cuerpo electoral en la Ley de 1837, en «Revista del Instituto de Ciencias Sociales», núm. 6, Barcelona, 1965.

- Las elecciones de 1844, en «Revista de Estudios Políticos», núm. 211, enerofebrero 1977, págs. 61-122.

- Las primeras elecciones directas en España. Artes Gráficas Soler, Valencia, 1965.

Trujillo, Gumersindo: El federalismo español. Cuadernos para el Diálogo, Madrid, 1967.

TuÑón DE LARA, Manuel: Estudios sobre el siglo XIX español, 3. ${ }^{a}$ ed. Siglo XXI de España, editores, Madrid, 1973

- La España del siglo XIX. Ed. Laia, Barcelona, 1974.

- La España del siglo XX. Librería Española, París, 1973.

- Historia y realidad del poder. Cuadernos para el Diálogo, Madrid, 1967.

Tusell Gómez, Javier: Una elección en la época caciquil: Guadalajara, 1907, en «Revista Española de Investigaciones Sociológicas», núm. 6, abril-junio 1979, págs. 53-83.

- Elecciones del Frente Popular, en «Historia», febrero, 1977.

- Las elecciones del Frente Popular. Tomos I y II. Cuadernos para el Diálogo, Madrid, 1971.

- Modernización política en la España del primer tercio del siglo XX, en «Revista de la Universidad de Madrid». Vol. XXI, núm. 81, págs. 183-201.

- Oligarquía y caciquismo en Andalucía (1890-1923). Ed. Planeta, Barcelona, 1976.

- Para la sociología política de la España contemporánea; el impacto de la Ley de 1907 en el comportamiento electoral, en «Hispania», XXX (1970), págs. 571361.

- Sociología electoral de Madrid (1903-1931). Cuadernos para el Diálogo, Madrid, 1969.

Ull Pont, Eugenio J.: El sufragio censitario en el Derecho electoral español, en «Revista de Estudios Políticos», núm. 194, pág. 125.

- Derecbo electoral de España (1810-1967). Tesis doctoral leída el 30 de abril de 1970. Texto mecanografiado inédito.

- Orígenes del Derecho electoral español, en «Boletín Informativo del Departamento de Derecho Político», UNED, núm. 2, 1978-79, págs. 31-53.

- El sufragio universal en España (1890-1936), en «Revista de Estudios Políticos», núms. 208-209, julio-octubre 1967, págs. 105-130.

VALCÁRCEL, Antonio: Sistema de gobierno republicano, democrático, federal al alcance del pueblo. Imprenta de José Noguera, Madrid, 1869.

Vanaclocha, Francisco J., y Laboa, Juan María: El referéndum en España, en «Historia», noviembre, 1976.

VANAclocha, Francisco J.: La ficción del coto obligatorio, en «Historia», abril 1977, págs. 23-31.

Varela, Santiago: Partidos y Parlamento en la II República. Fundación Juan March y Ariel, Barcelona, 1978.

Velasco PadRino, Aurelio: Reforma del régimen representativo. Tip. Lit. de J. García de la Chica, Madrid, 1898.

Vico y Brabo, Juan de Dios: Estudios elementales de Derecbo político y administrativo español. Imprenta de F. de los Reyes, Granada, 1879. 
Vidal Beneyto, José: Elecciones municipales y referéndum. Nota sobre las elecciones municipales por el tercio familiar del Ayuntamiento de Madrid del 20 de noviembre de 1966. Imp. Tanagra, Madrid, 1966.

VIlladA, P.: Las elecciones legislativas de 1910, en «Razón y Fe», mayo-agosto 1910 , págs. $75-80$.

Villanova, Genaro: Elección del distrito de Tíjola, provincia de Almería, en el año de 1858. Imp. de Luis García, Madrid, 1858.

Villanueva y Gómez, Miguel: Régimen representativo y parlamentario. (Discurso leído en el acto de su recepción, el día 15 de diciembre de 1929, en la Real Academia de Ciencias Morales y Políticas.) Imp. Viuda e Hijos de Jaime Ratés, Madrid, 1929.

Vivanco, Manuel, y SAN Martín, Luis: La reforma electoral para diputados a Cortes. Madrid, 1907.

Zancada, Práxedes: Las elecciones legislativas en España. González y Giménez impresores y editores, Madrid, 1914. 